\title{
Employee Retention at Indira Projects and Developments (T) Private Limited, Chennai
}

\author{
Nanda Kumar, S. Praveen Kumar
}

\begin{abstract}
Holding representatives is a basic and progressing exertion. Probably the greatest test in having directors in the spot that comprehends it is their duty to make and support a domain that cultivates maintenance. Staff requires support, course and acknowledgment to develop and stay fulfilled in their positions. Administrators must perceive this and comprehend that setting up such basics exhibits their goals to help nature and rouse etheir workers.

The primary targets of this examination is to know the reasons, why wearing down happens, to recognize the elements which cause representatives to disappoint, to know the agreeable degree of representatives towards their activity and working conditions and to discover the regions where indira undertaking and advancement businesses.

Maintenance is an intentional move by an association to make a situation which draws in workers as long as possible. An increasingly point by point and late meaning of the idea of maintenance is 'to keep the loss of skilled representatives from leaving efficiency and productivity. "Worker Retention is an orderly exertion by representatives to make and cultivate a situation that address the issues of the present workers and urges them to stay utilized by having strategies and practices set up that address their various needs".
\end{abstract}

Keywords: Work Retention, Efficiency, Productivity

\section{INTRODUCTION}

Work relations, independent of the business, time, spot, and individuals drew in, and culture, is common, complementary, and reliant. A significant part of all work relations is coherence. However, neither the business nor the representatives are guaranteed of that coherence in common relations for reasons that might include both or both of them. During an era of monetary and business solidness the connections between the two are steady. It additionally advances a feeling of duty and unwaveringness toward the association and the activity. Yet, in an unstable situation or in an air of quick industrialization the conditions change. The development and improvement of new enterprises while giving chances to the administration and the workers present numerous issues and difficulties. Associations in the new business consistently face the shortage of right sort of labor. This circumstance regularly acquires numerous difficulties

Revised Manuscript Received on July 22, 2019.

Nanda Kumar, Department of MBA, Bharath Institute of Higher Education and Research, Chennai, India.

Email: praveenkumar.mba@bharathuniv.ac.in

Dr. S. Praveen Kumar, Department of MBA, Bharath Institute of Higher Education and Research, Chennai, India.

Email: praveenkumar.mba@bharathuniv.ac.in

to the business while giving wide chances and advantages to the representatives (work searchers). [1],[3],[5]

The most basic test the businesses particularly in new enterprises face is the high pace of whittling down brought about by the shortage of labor combined with constantly expanding interest for labor. The test the business countenances isn't simply restricted to high steady loss rate yet the more significant issue is holding the performing workers in their occupations and with the association for a moderately longer timeframe. The business needs to convey every one of his abilities and knowledge in holding the workers and keeping the wearing down rate at a low level.

This is the circumstance the businesses in the Construction business in India Singapore and Thailand are experiencing. In this industry new associations are consistently coming into business as it is comprehensively quickly developing industry. Yet, they have the issue of getting and holding the correct sort of workers. The business is youthful and the labor is similarly youthful while the work open doors for the youthful representatives are not constrained to the nearby work showcase but rather reach out to the worldwide work advertise since the business is developing all around [2],[4],[6]

\section{STATISTICAL TOOLS USED FOR ANALYSIS}

The primary data have been collected from the potential respondents from different areas and has been properly sorted, classified, edited, tabulated in a proper format and analyzed by deploying appropriate statistical tools. The statistical tests are conducted at 5 per cent level of significance. The following statistical tools are used.

- Descriptive Analysis.

Table 1 - Provision To Avoid Sound In Plant Is Good

\begin{tabular}{|l|l|l|}
\hline PARTICULAR & FREQUENCY & PERCENTAGE \\
\hline Strongly Disagree & 6 & 6 \\
\hline Disagree & 16 & 16 \\
\hline Neutral & 39 & 39 \\
\hline Agree & 29 & 29 \\
\hline Strongly Agree & 10 & 10 \\
\hline Total & $\mathbf{1 0 0}$ & $\mathbf{1 0 0}$ \\
\hline Source: Primary data &
\end{tabular}

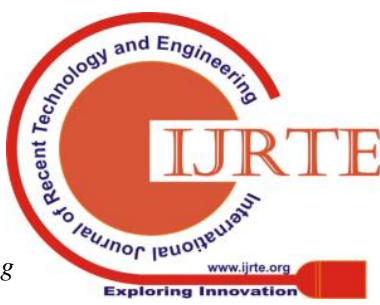




\section{Employee Retention at Indira Projects And Developments (T) Private Limited, Chennai}

Figure 1 - Provision To Avoid Sound In Plant Is Good

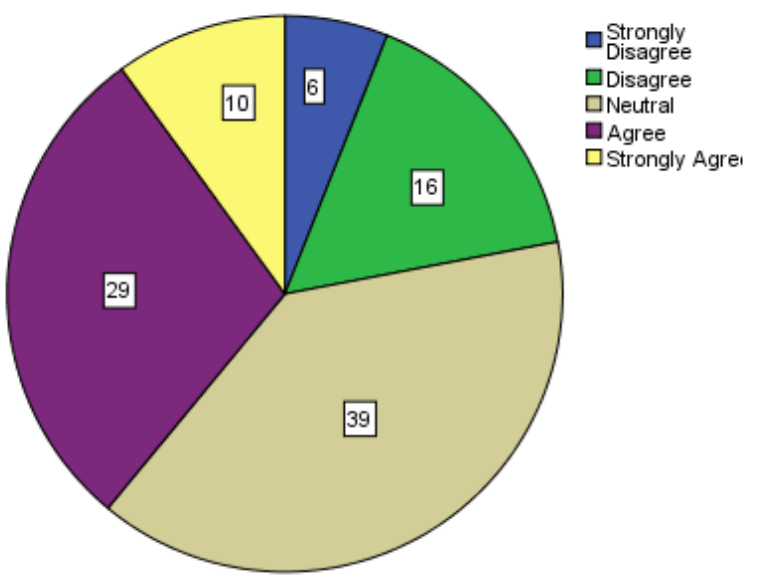

\section{Inference:}

It can be seen from Table 4.9 that $6 \%$ of the respondents rated Strongly Disagree $16 \%$ of the respondents are Disagree, $39 \%$ of the respondent are rated Neutral, $29 \%$ of the respondents are rated as Agree, and remaining $10 \%$ of the respondents strongly disagree.

Table 2 - Cleanliness Maintained in the Organization is Good

\begin{tabular}{|l|l|l|}
\hline PARTICULAR & FREQUENCY & PERCENTAGE \\
\hline Strongly Disagree & 3 & 3 \\
\hline Disagree & 14 & 14 \\
\hline Neutral & 30 & 30 \\
\hline Agree & 45 & 45 \\
\hline Strongly Agree & 8 & 8 \\
\hline Total & $\mathbf{1 0 0}$ & $\mathbf{1 0 0}$ \\
\hline Source: Primary data & \multicolumn{2}{|l}{}
\end{tabular}

Figure2 - Cleanliness Maintained in the Organization is Good

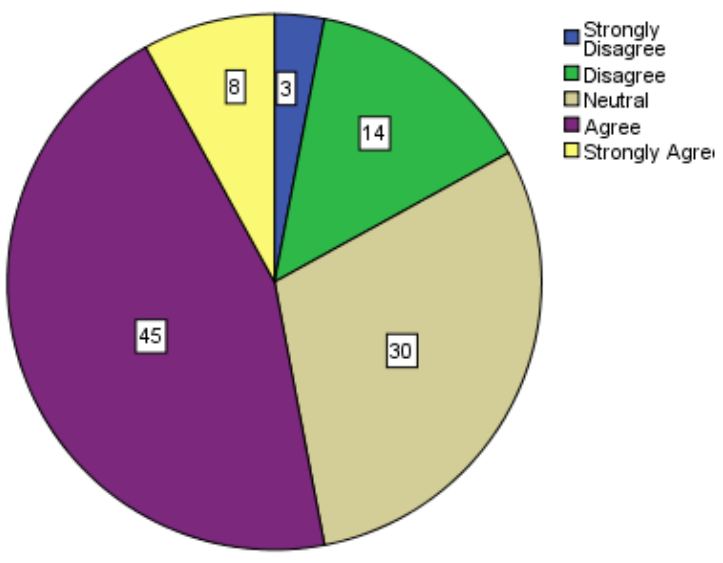

Inference:

It can be seen from Table 4.10 that $3 \%$ of the respondents rated Strongly Disagree $14 \%$ of the respondents are Disagree, $30 \%$ of the respondent are rated Neutral, $45 \%$ of the respondents are rated as Agree, and remaining 8\% of the respondents strongly disagree.

Table 3 - Working Environment is Comfortable

\begin{tabular}{|l|l|l|}
\hline PARTICULAR & FREQUENCY & PERCENTAGE \\
\hline Strongly Disagree & 1 & 1 \\
\hline Disagree & 14 & 14 \\
\hline Neutral & 45 & 45 \\
\hline Agree & 30 & 30 \\
\hline Strongly Agree & 10 & 10 \\
\hline Total & $\mathbf{1 0 0}$ & $\mathbf{1 0 0}$ \\
\hline Source: Primary data & &
\end{tabular}

Figure - 3 Working Environment is Comfortable

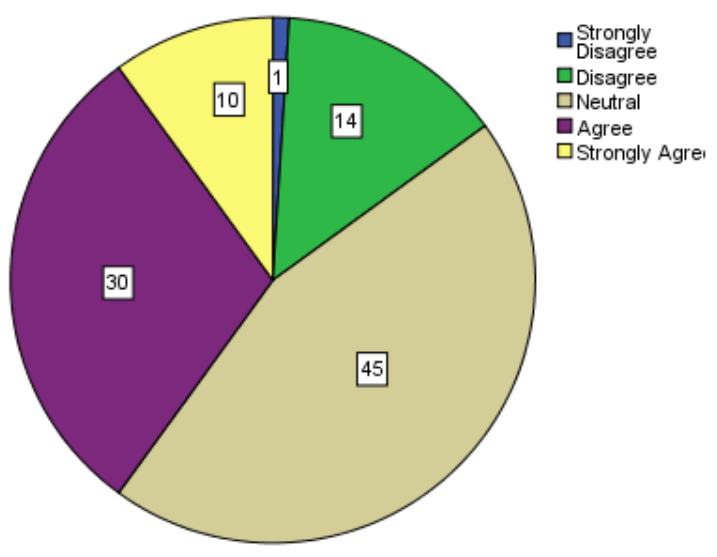

\section{Inference:}

It can be seen from Table 4.11 that $1 \%$ of the respondents rated Strongly Disagree $14 \%$ of the respondents are Disagree, $45 \%$ of the respondent are rated Neutral, $30 \%$ of the respondents are rated as Agree, and remaining 10\% of the respondents strongly disagree.

Table 4 - First aid box maintained at work place are good

\begin{tabular}{|l|l|l|}
\hline PARTICULAR & FREQUENCY & PERCENTAGE \\
\hline Strongly Disagree & 3 & 3 \\
\hline Disagree & 8 & 8 \\
\hline Neutral & 29 & 29 \\
\hline Agree & 38 & 38 \\
\hline Strongly Agree & 22 & 22 \\
\hline Total & $\mathbf{1 0 0}$ & $\mathbf{1 0 0 . 0}$ \\
\hline
\end{tabular}

Source: Primary data 
Figure 4 - First aid box maintained at work place are good

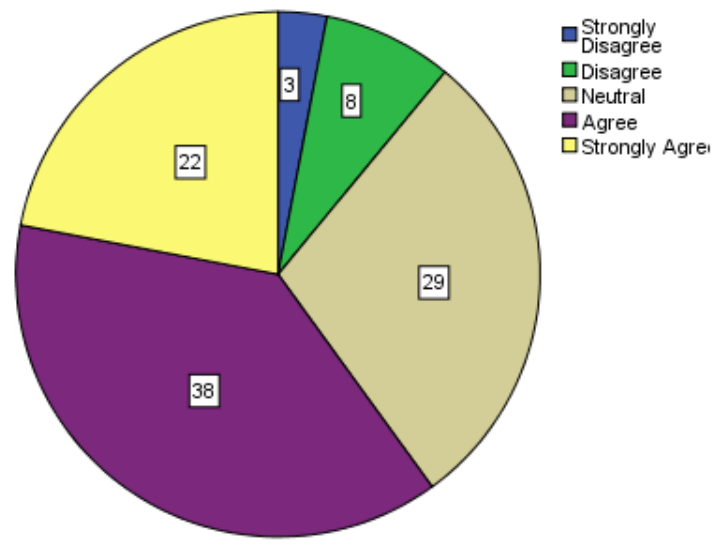

\section{Inference:}

It can be seen from Table 4.12 that $3 \%$ of the respondents rated Strongly Disagree $8 \%$ of the respondents are Disagree, $25 \%$ of the respondent are rated Neutral, $38 \%$ of the respondents are rated as Agree, and remaining $22 \%$ of the respondents strongly disagree.

\section{RESULTS}

It can be seen from Table 4.1 that $61 \%$ of the respondents evaluated Female; $39 \%$ of the respondents appraised Female.

It can be seen from Table 4.2 that $22 \%$ of the respondents evaluated Below 20 years; $33 \%$ of the respondents appraised 21-30 years; $24 \%$ of the respondent evaluated $31-40$ years; $21 \%$ of the respondent evaluated above 41 years.

It can be seen from Table 4.3 that $54 \%$ of the respondents evaluated Married; $46 \%$ of the respondents appraised Unmarried. [7], [9] ,[11]

It can be seen from Table 4.4 demonstrates that $26 \%$ of the respondents evaluated Below 15000; $28 \%$ of the respondents $15001-20000.30 \%$ of the respondent appraised 20001-30000; $16 \%$ of the respondent evaluated Above 30,000 .

It can be seen from Table 4.5 that $8 \%$ of the respondents evaluated Strongly Disagree $20 \%$ of the respondents are Disagree, $32 \%$ of the respondent are appraised Neutral, and $31 \%$ of the respondents are appraised as Agree, remaining $12 \%$ of the respondents are Strongly oppose this idea.

It can be seen from Table 4.6 that $9 \%$ of the respondents appraised Strongly Disagree $28 \%$ of the respondents are Disagree, $32 \%$ of the respondent are evaluated Neutral, and $23 \%$ of the respondents are evaluated as Agree, remaining $8 \%$ of the respondents are Strongly oppose this idea. [8], [10],[12]

- It can be seen from Table 4.7 that $10 \%$ of the respondents appraised Strongly Disagree $24 \%$ of the respondents are Disagree, $33 \%$ of the respondent are evaluated Neutral, $26 \%$ of the respondents are evaluated as Agree, remaining 7\% of the respondents are Strongly oppose this idea.

- It can be seen from Table 4.8 that $5 \%$ of the respondents evaluated Strongly Disagree $23 \%$ of the respondents are Disagree; $35 \%$ of the respondent are appraised Neutral, 23\% of the respondents are appraised as Agree, staying $14 \%$ of the respondents are Strongly oppose this idea.

- It can be seen from Table 4.9 that $6 \%$ of the respondents appraised Strongly Disagree $16 \%$ of the respondents are Disagree, $39 \%$ of the respondent are evaluated Neutral, $29 \%$ of the respondents are appraised as Agree, and staying $10 \%$ of the respondents firmly oppose this idea.

It can be seen from Table 4.10 that $3 \%$ of the respondents appraised Strongly Disagree 14\% of the respondents are Disagree, $30 \%$ of the respondent are evaluated Neutral, $45 \%$ of the respondents are appraised as Agree, and remaining $8 \%$ of the respondents firmly oppose this idea.

- It can be seen from Table 4.11 that $1 \%$ of the respondents evaluated Strongly Disagree $14 \%$ of the respondents are Disagree, $45 \%$ of the respondent are appraised Neutral, $30 \%$ of the respondents are appraised as Agree, and staying $10 \%$ of the respondents unequivocally oppose this idea.

- It can be seen from Table 4.12 that $3 \%$ of the respondents evaluated Strongly Disagree $8 \%$ of the respondents are Disagree, 25\% of the respondent are appraised Neutral, $38 \%$ of the respondents are appraised as Agree, and staying $22 \%$ of the respondents unequivocally oppose this idea.

- It can be seen from Table 4.13 that $3 \%$ of the respondents appraised Strongly Disagree 16\% of the respondents are Disagree, $35 \%$ of the respondent are evaluated Neutral, $33 \%$ of the respondents are evaluated as Agree, and staying $13 \%$ of the respondents unequivocally oppose this idea. [13], [15],[17]

- It can be seen from Table 4.14 that $3 \%$ of the respondents appraised Strongly Disagree $6 \%$ of the respondents are Disagree, 29\% of the respondent are evaluated Neutral, $47 \%$ of the respondents are evaluated as Agree, and staying $15 \%$ of the respondents unequivocally oppose this idea.

- It can be seen from Table 4.15 that $5 \%$ of the respondents evaluated Strongly Disagree $23 \%$ of the respondents are Disagree, 35\% of the respondent are appraised 
Neutral, $23 \%$ of the respondents are appraised as Agree, and staying $14 \%$ of the respondents emphatically oppose this idea.

It can be seen from Table 4.16 that $6 \%$ of the respondents evaluated Strongly Disagree $8 \%$ of the respondents are Disagree, $27 \%$ of the respondent are appraised Neutral, $45 \%$ of the respondents are appraised as Agree, and staying $14 \%$ of the respondents emphatically oppose this idea.

- It can be seen from Table 4.17 that $4 \%$ of the respondents appraised Strongly Disagree $9 \%$ of the respondents are Disagree, $31 \%$ of the respondent are evaluated Neutral, $35 \%$ of the respondents are appraised as Agree and remaining $21 \%$ of the respondents unequivocally oppose this idea.

- It can be seen from Table 4.18 that $5 \%$ of the respondents evaluated Strongly Disagree $22 \%$ of the respondents are Disagree, $30 \%$ of the respondent are appraised Neutral, $29 \%$ of the respondents are evaluated as Agree, and remaining $14 \%$ of the respondents unequivocally oppose this idea. [14], [16],[18]

\section{DISCUSSIONS}

Strategy fundamentally infers that the administration of associations think modernly to deal with the troublesome circumstances in future. They attempt to characterize the future/planned strategy. The issue of worker maintenance is a perpetual proble $4 \mathrm{~m}$ in the work rare industry like the indira the administrations in this industry ought to have their strategies characterized concerning how they ought to be manage the issue and confine the issue influencing the association. Despite the fact that we have recorded 101 systems the IT organizations in Bangalore have embraced, it is proposed that they have to think and received their strategies on representative maintenance offering essentialness to the accompanying key regions of worker maintenance: [19], [21],[23]

Flexible Workplace and Work: The indira undertaking and advancement industry in every case needs to employ the learning/proficient specialists. The expert laborers should be overseen by giving them adaptability of working for the association enlisting them. Where the representative feels that he needs adaptable working he may not adhere on to the association. Henceforth, the organizations that don't have the arrangement of adaptability in the working frameworks need to make it an approach to accommodate adaptable work frameworks and work place courses of action.

Total Employee Engagement: The expert representatives likewise want to be definitively occupied with their work and association. Such a workplace empowers to be progressively imaginative and creative. Both the association and the representative are profited by a workplace that accommodates complete worker commitment. Subsequently, the administrations should think and always audit the worker commitment programs. It ought to be a strategy of the undertaking and improvement. Subsequently, it is basic that

administration to survey and reformulation. [20], [22], [24]

Employment Equity: The information laborers or the expert workers likewise like and anticipate an impartial business. The real work or assignments may fluctuate, however the terms and states of business can't be biased. The representatives do oppose the unjust work. Henceforth, giving business value likewise should be a customary and articulated arrangement that makes the representatives to adhere on to the association.

Encourage Performance: Proficient representatives do want to perform and perform to assist the association just as for their vocation development and advancement. Subsequently, it ought to be the strategy of the association to urge their representatives to perform continually. They have to give a favorable environment to execution. Performing workers when sufficiently remunerated would adhere on to the association. The administrations ought to perceive this reality through a satisfactory strategy measure.

Boost Employees' Self-Esteem: By and by it is a fact that the expert workers give very significance to confidence in their business and calling. They would not proceed in a business where their confidence is in question. Consequently, the administrations when all is said in done and the HR supervisors specifically ought to make a domain that guarantees confidence of the workers all in all and of the IT experts specifically. The work and commitments made by the expert representatives should be exceedingly valued and compensated. Extraordinary measures ought to be arranged and created to support the worker confidence. It will likewise be a fundamental arrangement of the association.

Sense of Ownership: Another significant practice the associations ought to embrace as an approach is to make a feeling of organization in the association with respect to its representatives are worried through different estimates, for example, Employee Stock Ownership programs. At the point when the workers feel that they are accomplices in the association - might be to a little degree - they reconsider before leaving the association. Subsequently, it ought to be a strategy of the administration to make chances of worker possession in the association through representative stock proprietorship programs as well as through different methods. [25], [27], [29]

\section{V.CONCLUSION}

HR the executives rehearses the world over demonstrates that the job of the HR experts is evolving quickly. They are currently increasingly proactive. The essential job of a HR proficient in future is empower the line directors to play out the job of a HR chief just as choose enrollment, preparing and so on. The HR director's job will turn into the job of a teacher, where he engages, empowers the line administrators and in this manner makes the customary HR elements of a work force supervisor, out of date. There may be not many HR experts in the association however their jobs will be significant. [26], [28], [30]

\section{Representative maintenance as a}


term did not hold a similar significance over the diverse business fragments. For organizations working in the customary business it was interpreted as holding just great representatives and propelling them to perform well. Nonetheless, organizations working in the indira undertaking and advancement are of the conclusion that maintenance means holding every one of the representatives in the organization since the organization has put a great deal in every last one of them.

The indira venture and advancement industry has announced the issue of maintenance to be the most astounding pursued by the promoting organizations. The issue of worker maintenance is connected with the quantity of representatives - it increments with the quantity of workers. It has additionally been believed to be connected with the size of the organization. The average sized organizations face this issue to an enormous degree. Worker maintenance is a territory of worry in organizations working in moderate development businesses. Representative maintenance is in this manner a component of the quantity of workers, the size of the organization and the pace of development of the business. [31], [33]

The issue of representative maintenance is higher among the lesser level workers over every one of the businesses. In any case, in the dawn enterprises and the indira task and advancement industry the turnover rates are high in the center just as senior levels. Over all industry sections, the turnover among the specialized staff is higher than the non specialized staff. In any case, it is most noteworthy in the IT. The substitution just as the enlistment rate for new business is on a decrease in the customary and administrations enterprises. The enlistment rate for substitution just as new business has seen high development among promoting and IT organizations.

Size loans soundness to the maintenance levels. Degrees of consistency have declined in the medium estimated organizations however have gone up in enormous measured associations. Customary organizations notice that maintenance of workers isn't an issue at all since at the season of subsidence in the business representatives are hesitant to leave. In advertising organizations maintenance levels had gone up because of better development openings inside the organization however if there should be an occurrence of administration businesses the turnover has been fast as most open doors are detected outside. In the indira undertaking and advancement industry, be that as it may, the turnover rates have expanded at all levels however most organizations have turned out to be cognizant towards this and have presented better working conditions and remuneration bundles for all levels and specialized just as non specialized representatives.

\section{REFERENCES}

1) BharthVajan R., Ramachandran S.,Psychographic dimensions of training,2016,International Journal of Pharmacy and Technology,V-8,I-4,P-23727-23729

2) Balakrishnan P., Bharthvajan R.,A study on human resource planning in hospitals in Chennai City,2014,International Journal of Applied Engineering Research,V-9,I-22,P-7503-7507

3) Priyadarsini P., Bharthvajan R.,Role of emotional intelligence training programme in reducing the stress of the nurses,2014,International Journal of Applied Engineering Research,V-9,I-22,P-7411-7421

4) Kerinab Beenu G., Bharthvajan R.,Empirical analysis on the cosmetic buying behavior of young women in South India,2014,International Journal of Applied Engineering Research,V-9,I-22,P-7361-7366

5) Balakrishnan P., Bharthvajan R.,Whistling in the wind,2014,International Journal of Applied Engineering Research,V-9,I-22,P-7586-7593

6) Krishnan B., Peter M.,Health hazards of Indian Bpo employee-an alarming issue,2014,International Journal of Applied Engineering Research,V-9,I-22,P-7336-7341

7) Kerinab Beenu G.H., Peter M.,Role of insurance in economic development,2014,International Journal of Applied Engineering Research,V-9,I-22,P-7532-7539

8) Balakrishnan P., Peter M., Priyadarsini P.,Efficiency of safety measures for wellbeing of employees in manufacturing industry,2014,International Journal of Applied Engineering Research,V-9,I-22,P-7376-7382

9) Anbarasi M., Praveen Kumar S.,Online sales promotions of herbal products and its effectiveness towards tanisha.com,2019,Indian Journal of Public Health Research and Development,V-10,I-1,P-195-200

10) Anbarasi M., Praveen Kumar S.,Various online marketing and promotions strategies to improve the validation towards the organic products in the pharmaceutical sectors,2019,Indian Journal of Public Health Research and Development,V-10,I-1,P-263-269

11) Loganathan R., Praveen Kumar S.,Grievance handling a key factor for solving issues of employees in an organization,2014,International Journal of Applied Engineering Research,V-9,I-22,P-7483-7491

12) Loganathan R., Praveen Kumar S.,Study on preference of private label brands in super and Hypermarkets, 2014,International Journal of Applied Engineering Research,V-9,I-22,P-7327-7335

13) Smitha M., Praveen Kumar S.,Understanding stress and its managementamong the nurses in Chennai city,2014,International Journal of Applied Engineering Research,V-9,I-22,P-7560-7565

14) Kerinab Beenu G.H., Praveen Kumar S.,A study on the investment behavior of Chennai investors in mutual fund schemes,2014,International Journal of Applied Engineering Research,V-9,I-22,P-7520-7525

15) Loganathan R., Praveen Kumar S.,Retention strategies key for organizational productivity,2014,International Journal of Applied Engineering Research,V-9,I-22,P-7443-7447

16) Pavithra J., Ganesan M., Brindha G.,State wise analysis of microfinance sector in India,2016, International Journal of Pharmacy and Technology,V-8,I-4,P-23417-23432

17) Pavithra J., Ganesan M.,A comparative study on microfinance in India and abroad,2016,International Journal of Applied Business and Economic Research,V-14,I-8,P-5471-5476

18) Pavithra J., Ganesan M.,A study on awareness and impact of micro-financial schemes,2016,International Journal of Applied Business and Economic Research,V-14,I-8,P-5449-5460

19) Senthilmurugan P., Pavithra J.,Consumer preference towards organised retailing with reference to Big Bazaar,2014,International Journal of Applied Engineering Research,V-9,I-22,P-7469-7475

20) Senthilmurugan P., Pavithra J.,Implication of social media marketing in growing healthcare industry,2014,International Journal of Applied Engineering Research,V-9,I-22,P-7448-7456

21) Loganathan R., Pavithra J.,Consumer perception towards private label brand over other brands in super markets and hypermarkets,2014,International Journal of Applied Engineering Research,V-9,I-22,P-7355-7360

22) Kerinab Beenu G., Pavithra J.,Tradeâ€"off between liquidity and profitability in logistics industry,2014,International Journal of Applied Engineering Research,V-9,I-22,P-7398-7401

23) Kerinab Beenu G., Pavithra J.,A study on the prospective consumerâ $€^{\mathrm{TM}_{S}}$ perception towards utility cars in Chennai city,2014,International Journal of Applied Engineering Research,V-9,I-22,P-7526-7531

24) Pavithra J., Dilli Babu P., Ambuli T.V.,A study on budgetary control at Maruti Service Masters, Chennai,2014,International Journal of Applied Business and Economic Research,V-12,I-2,P-151-161

25) Pavithra J., Dilli Babu P., Ambuli T.V.,A study on customer satisfaction of retro Garments Pvt Ltd, Chennai,2014,International Journal of Applied Business and Economic Research,V-12,I-2,P-381-391

26) Kerinab Beenu G.H., Pavithra J., Senthilmurugan P.,A study on the influence of promotional activities for TATA ARIA among consumers in Chennai,2014,International Journal of Applied Engineering Research,V-9,I-22,P-7572-7578

27) Vijayaragavan S.P.,An investigative expert that's general FBG sensors,International Journal of Mechanical Engineering and 
Technology,V-8,I-8,PP-1500-1505,Y-2017

28) Vijayaragavan S.P.,Equalization routing protocol for Wi-Fi sensor strategy,International Journal of Mechanical Engineering and Technology,V-8,I-8,PP-1662-1666,Y-2017

29) Karthik B., Kiran Kumar T.V.U., Vijayaragavan P., Bharath Kumaran E.,Design of a digital PLL using 0.35 $\hat{\mathrm{I}}^{1} / 4 \mathrm{~m}$ CMOS technology,Middle East Journal of Scientific Research,V-18,I-12,PP-1803-1806,Y-2013

30) Kanniga E., Selvaramarathnam K., Sundararajan M.,Kandigital bike operating system,Middle - East Journal of Scientific Research,V

31) Jasmin M., Vigneshwaran T., Beulah Hemalatha S.,Design of power aware on chip embedded memory based FSM encoding in FPGA,International Journal of Applied Engineering Research,V-10,I-2,PP-4487-4496,Y-2015

32) Jasmin M.,Optimization techniques for low power VLSI circuits,Middle East Journal of Scientific Research,V-20,I-9,PP-1082-1087,Y-2014

33) Jasmin M., Vigneswaran T.,Fuzzy controller for error control of on - Chip communication,2017 International Conference on Algorithms, Methodology, Models and Applications in Emerging Technologies, ICAMMAET 2017,V-2017-January,I-,PP-1-5,Y-2017

\section{AUTHORS PROFILE}

Nanda Kumar Research Scholar, Department of MBA, Bharath Institute of Higher Education and Research, Chennai, India.

Dr. S. Praveen Kumar Professor, Department of MBA, Bharath Institute of Higher Education and Research, Chennai, India. 